\title{
Complementary, Alternative and Conven- tional Medicine Attitude Scale: Turkish Validity Reliability Study
} Geleneksel ve Tamamlayıc Tıp Tutum Ölçeği:

\section{Türkçe Geçerlilik ve Güvenirlik Çalışması}

\author{
Elif Köse', Hasan Çetin Ekerbiçer², Ünal Erkorkmaz ${ }^{3}$ \\ 1 Public Health Directorate, Gaziantep \\ ${ }^{2}$ Sakarya University Faculty of Medicine, Department of Publibc Health, Sakarya \\ ${ }^{3}$ Sakarya University Faculty of Medicine, Department of Biostatistics, Sakarya \\ Yazışma Adresi / Correspondence: \\ Elif Köse \\ Gaziantep Provincial Health Directorate 42035 Street. Number: 40 Şehitkâmil / Gaziantep, 27060 \\ T: +90342 2209614 E-mail: elifyldzkose@gmail.com
}

Geliş Tarihi / Received : 02.11.2018 Kabul Tarihi / Accepted : 03.12.2018

The study has been presented orally in HESTOUREX World Health Sport Tourism Congress and Exhibition, April 6-9, 2017.

\footnotetext{
Abstract

Objective Societal attitudes among those with access to health services concerning traditional and complementary medicine provide important information for policymakers seeking to understand the quality of these services. Few scales exist in the Turkish language that address this information for policymakers seeking to understand the quality of these services. Few scales exist in the Turkish language that address this
issue. Thus, in this study, the Complementary, Alternative, and Conventional Medicine Attitude Scale (CACMAS) of McFadden et al. was adapted in Turkish, and the validity and reliability of the scale were assessed. ( Sakarya Med J 2018, 8(4):726-736 )

Material and The population of the methodological and descriptive research consists of executive staff working in all units of Sakarya University. In the

Methods study, 597 people $(79.5 \%)$ who accepted to participate were included, with a mean age of $38.91 \pm 9.62$ years. The psychometric properties of the scale were analyzed and exploratory factor analysis, confirmatory factor analysis, compliance testing, internal consistency, and testretest analysis were performed.

Results The three subscales of the CACMAS had an internal consistency reliability coefficient of 0.808 . Moreover, confirmatory factor analysis of compliance done using the chi square test, produced a value of $1,644.07$ (degrees of freedom $(\mathrm{df})=324 \cdot \mathrm{p}<0.001$ ). The root mean square error of approximation, goodness of fit, and adjusted goodness of fit values were $0.090,0.809$, and 0.777 , respectively.

Conclusion The CACMAS adapted in Turkish is a valid and reliable scale that can be used in the planning of healthcare services.

A limitation of this study was that $82.4 \%$ of the participants had an education level above high school, indicating an overall high level of education. Further studies evaluating the validity and reliability of this scale in other Turkish populations are warranted.

Keywords Complementary medicine; traditional medicine; scale; validity and reliability
}

Öz

Amaç Geleneksel ve tamamlayıcı tıp ile ilgili sağlık hizmeti alan toplumların tamamlayııı tıp ile ilgili tutumlarını saptamak, bu hizmetlerin kalitesini anlamaya çalışan politika yapıcılar için önemli bilgiler sağlamaktadır. Bu konu ile ilgili çok az sayıda Türkçe ölcçek vardır. Bu nedenle, bu çalıșmada, McFadden ve ark'nın Tamamlayıcı, Alternatif ve Geleneksel Tıp Tutum Ölçeği (CACMAS) Türkçeye uyarlanmış, ölçeğin geçerliliği ve güvenilirliği değerlendirilmiștir. ( Sakarya Tıp Dergisi 2018, 8(4):726-736 ).

Gereç ve Metodoloijk ve tanımlayıc nitelikteki arastırmann evrenini Sakarya Üniversitesi'nin tüm birimlerinde calışan idari personel olusturmaktadir.

Yöntem Katılmayı kabul eden 597 kișinin $(\% 79,5)$ yaș ortalaması $38.91 \pm 9.62$ 'dir. Ölcceğin psikometrik özellikleri analiz edilmiș ve açıklayıcı faktör analizi, doğrulayıcı faktör analizi, uyum testi, iç tutarllık ve test-tekrar test analizleri yapılımıştı.

Bulgular Üç alt ölçeği olan CACMAS'ın iç tutarılıık güvenirlik katsayısı 0.808 'dir. Ayrıca, doğrulayıcı faktör analizi uyum indekslerinden ki kare uyum testi 1644,07 (serbestlik derecesi $(\mathrm{df})=324 ; p<0.001$ ) olarak saptanmıştır. Ortalama karekök hatası, uyum iyiliği ve ayarlanmış uyum iyiliği değerleri sırasılyla $0.090,0.809$ ve 0.777 bulunmuştur.

Sonuç Türkçeye uyarlanan CACMAS, sağlık hizmetlerinin planlanmasında kullanılabilecek geçerli ve güvenilir bir ölçektir. Bu çalışmanın bir kısıtlıı̆̆ı, katılımcıların \% 82.4'ünün lisenin üzerinde, yüksek eğitim seviyesine sahip olmasıdır. Bu ölçeğin farklı popülasyonlarda da kullanılabilmesi için, Türkçe geçerlilik ve güvenilirliğini değerlendiren bașka çalışmalar gereklidir. 


\section{Introduction}

The rate of use of traditional medicine to treat disease varies by country, geographical region, and time period. ${ }^{2}$ The health belief model may be an important tool to assess the attitude of individuals toward conventional and complementary medicine practices (CCMP). Although some people prefer modern medical practices and have a negative attitude toward CCMP, others value CCMP because they align with their own health standards and beliefs.

The use of and interest in traditional and complementary medical practices has been increasing, warranting further research concerning these practices. ${ }^{3-5}$ Previously, McFadden et al. created the Complementary, Alternative, and Conventional Medicine Attitudes Scale (CACMAS), which shows personal health belief modify their treatment and was previously tested on 2010 university graduates. ${ }^{1}$ The CACMAS includes three subscales: philosophical congruence with complementary and alternative medicine; dissatisfaction with conventional medicine; and holistic balance. The validity and reliability of the CACMAS were tested in army pensioners by Betthauser et al. ${ }^{6}$

The aim of the current study was to adapt the CACMAS for use in Turkish populations, to objectively determine attitudes and behaviors at both the individual and societal level toward traditional and complementary medical practices; this could facilitate health service planning by policymakers.

\section{Materials and Methods}

This descriptive and methodological study was performed at Sakarya University, Adapazarı, Turkey. In total, 642 of 751 executive staff personnel, drawn from all faculties, institutions, and schools of Sakarya University, accepted the invitation to participate in this study. The questionnaires of 45 participants were incomplete, and thus a total of 597 (79.5\%) responses were included in the final analysis. Of the participants, 375 (62.8\%) were male, and the mean age was $38.91 \pm 9.62$ years. Only $17.7 \%$ of participants had an education level below high school, and those who lived in a rural area composed only a small proportion of participants.

The first 26 questionnaire items were devised based on previous literature. Four, ten, and twelve questions explored sociodemographic characteristics, personal history (including of chronic diseases and typical health practices), and CCMP, respectively. The questionnaire also included the 27 questions of the CACMAS, which was adapted and translated into Turkish with permission from the original authors.

Each item was measured by a scale ranging from $0-7$, with 7 corresponding to "I highly agree" and 0 corresponding to "I highly disagree". No cut-off points were used, and a higher total number of points indicated a more positive view of traditional and complementary medicine. Surveys were completed under observation and the average time to complete the survey was 20 minutes.

The CACMAS was translated into Turkish by three different individuals with advanced knowledge of both English and Turkish. Three other individuals with advanced knowledge of English and Turkish subsequently back-translated the scale into English. To assess differences in meaning between the translated scales, another individual with English and Turkish language expertise was consulted and provided final feedback. 
The Davis technique was used to determine the validity of the CACMAS. Currently, scales are accepted as valid if the Davis value is 0.80 or more. ${ }^{7}$ In this study, the Davis value was 0.80 , signifying that the scale met the extant validity criterion.

Factor analysis was performed using the Kaiser-Meyer-Olkin (KMO) test and compliance was assessed using Bartlett's test. Moreover, structural validity (basic components method) was tested, and explanatory factor analysis and the Varimax rotation technique performed, for the 27 items of the CACMAS. ${ }^{8}$ If the factor loads derived from explanatory factor analysis were $\geq 0.3$, items were cared and be schemed. The results of explanatory factor analysis were reassessed according to the results of the confirmed factor analysis, and appropriation indices were calculated using root mean square error or approximation (RMSEA), goodness of fit (GFI), and adjusted GFI (AGFI). ${ }^{9}$ While grouping components CACMAS was used and parts of $27 \%$ subgroups Mann Whitney $U$ test was used.

Cronbach's alpha was used to determine the internal consistency of the CACMAS. All subscales points are got by counting all items' points with the help of Tukey countability test. Descriptive statistics for the CACMAS subscales are expressed as medians and interquartile ranges. Comparison of CACMAS scores by gender was done using the Mann-Whitney $U$ test. Pearson correlation test was used to assess stability according to time, while the Wilcoxon test was used to assess differences between pairs. ${ }^{10,11}$

A p-value $<0.05$ was considered to indicate statistical significance. Analyses were performed using SPSS software (ver. 13.0; IBM Corp., Armonk, NY, USA).

Permission to test the validity and reliability of the CACMAS was obtained from Theresa D. Hernandez via electronic mail. Ethical permission for the study was obtained from Sakarya University Noninvasive Research Ethical Academy and Sakarya University Rector, and all participants provided informed consent.

\section{Results \\ Validity}

The structural validity of the CACMAS was assessed using factor analysis techniques. Before the analysis, the $\mathrm{KMO}$ and Bartlett test were performed ( $\mathrm{KMO}=0.85$; Bartlett's test, $\rho<0.001)$, which indicated significance $(2=4910.768)$.

Exploratory factor analysis of the 27 questionnaire items was conducted to confirm the validity of the Turkish translation. Items with eigenvalues $>1$ were divided into three subscales, which together explained $40.51 \%$ of the total variance, as follows: philosophical congruence with complementary and alternative medicine, dissatisfaction with conventional medicine, and holistic balance. They accounted for $14.4 \%, 13.95 \%$, and $12.41 \%$ of the total variance, respectively. Based on the results of the item analysis, we decided not to remove any items from the CACMAS. Factor loading of the items ranged between 0.221 and 0.775 (Table 1).

Tukey's test of additivity was performed to determine whether the scale is designed in collectable type or not $(p<0.001)$. Differences in the mean CACMAS item points were significant according
Sakarya Med ]

2018;8(4):726-736 
to Hotelling's T2 test $(p<0.001)$. The distribution of the answers, average number of points per item, and standard deviations are shown in Table 2 (smallest value $2.78 \pm 1.91 \mathrm{SS}$; largest value $6.32 \pm 1.15 \mathrm{SS})$.

\begin{tabular}{|c|c|c|c|c|}
\hline \multicolumn{5}{|l|}{ Factor structures and factor loads* } \\
\hline & $\begin{array}{l}\text { Item } \\
\text { correlation }\end{array}$ & \multicolumn{3}{|c|}{ Factor } \\
\hline Item & & 1 & 2 & 3 \\
\hline $\begin{array}{l}\text { Philosophical congruence with complementary and } \\
\text { alternative medicine }\end{array}$ & \multicolumn{4}{|c|}{$\begin{array}{l}\text { Proportion of variance explained: } 14.4 \% \\
\text { Cronbach's alpha: } 0.827\end{array}$} \\
\hline $\begin{array}{l}\text { 19. I believe that the practice of ambulatory medicine has } \\
\text { enabled me to take control of my own health. }\end{array}$ & 0.598 & 0.775 & 0.117 & 0.204 \\
\hline $\begin{array}{l}\text { 18. I feel quite relieved after completing medical treatments or } \\
\text { after using complementary medical products. }\end{array}$ & 0.567 & 0.761 & 0.082 & 0.222 \\
\hline $\begin{array}{l}\text { 5. Compared to the suggestions and treatments of doctors, } \\
\text { I find that the suggestions and treatments of complementary } \\
\text { medicine more closely align with my values. }\end{array}$ & 0.499 & 0.703 & 0.092 & 0.080 \\
\hline $\begin{array}{l}\text { 7. I think complementary healing methods are more natural than } \\
\text { the treatments that doctors (modern medicine) use. }\end{array}$ & 0.515 & 0.638 & 0.058 & 0.221 \\
\hline $\begin{array}{l}\text { 21. Most traditional medical treatment methods activate the } \\
\text { healing power that our bodies have. }\end{array}$ & 0.566 & 0.626 & 0.045 & 0.385 \\
\hline $\begin{array}{l}\text { 22. Complementary medicine contains ideas and methods that } \\
\text { doctors can also benefit from. }\end{array}$ & 0.539 & 0.595 & -0.019 & 0.437 \\
\hline $\begin{array}{l}24 . \text { I believe that complementary medicine for health problems } \\
\text { will be more effective than doctors' recommendations. }\end{array}$ & 0.520 & 0.592 & 0.280 & 0.040 \\
\hline $\begin{array}{l}\text { 9. I think complementary medicine is a threat to public health } \\
\text { (reverse-scored). }\end{array}$ & 0.195 & 0.329 & -0.174 & -0.054 \\
\hline Dissatisfaction with conventional medicine & \multicolumn{4}{|c|}{$\begin{array}{l}\text { Proportion of variance explained: } 13.95 \% \\
\text { Cronbach's alpha: } 0.796\end{array}$} \\
\hline $\begin{array}{l}\text { 1. I was very pleased with the health services provided when I } \\
\text { last went to the doctor (reverse scored). }\end{array}$ & 0.316 & -0.053 & 0.690 & -0.180 \\
\hline $\begin{array}{l}\text { 16. It was difficult to talk to my doctor when I last went to the } \\
\text { doctor. }\end{array}$ & 0.492 & 0.075 & 0.682 & 0.196 \\
\hline $\begin{array}{l}\text { 14. When I last went to the doctor, the doctor did not under- } \\
\text { stand what the problem was. }\end{array}$ & 0.436 & 0.028 & 0.668 & 0.065 \\
\hline $\begin{array}{l}\text { 4. When I last went to the doctor, I understood the answers } \\
\text { given to the important questions I asked about my health } \\
\text { (reverse-scored). }\end{array}$ & 0.261 & -0.033 & 0.655 & -0.243 \\
\hline $\begin{array}{l}\text { 11. I do not trust doctors and hospitals, so I try to go as little as } \\
\text { possible. }\end{array}$ & 0.424 & 0.108 & 0.630 & $<0.001$ \\
\hline $\begin{array}{l}\text { 26. When I last went to the doctor, my treatment was effective } \\
\text { (reverse-scored). }\end{array}$ & 0.208 & 0.001 & 0.593 & -0.344 \\
\hline $\begin{array}{l}\text { 17. I am often worried that the treatments my doctor suggests } \\
\text { will have adverse side effects. }\end{array}$ & 0.505 & 0.194 & 0.562 & 0.154 \\
\hline $\begin{array}{l}\text { 8. I am very confident in the doctor I visit to receive healthcare } \\
\text { (reverse-scored). }\end{array}$ & 0.209 & 0.050 & 0.544 & -0.356 \\
\hline $\begin{array}{l}\text { 27. When I last went to the doctor, the doctor did not give me } \\
\text { enough time. }\end{array}$ & 0.370 & -0.106 & 0.532 & 0.221 \\
\hline 20. I prefer to treat my health problems on my own. & 0.424 & 0.283 & 0.347 & 0.128 \\
\hline
\end{tabular}




\begin{tabular}{|l|c|c|c|c|}
\hline & \multicolumn{2}{|c|}{$\begin{array}{c}\text { Item } \\
\text { correlation }\end{array}$} & \multicolumn{3}{|c|}{ Factor } \\
\hline Item & & 1 & 2 & 3 \\
\hline Holistic balance & \multicolumn{2}{|c|}{$\begin{array}{c}\text { Proportion of variance explained: } 12.41 \% \\
\text { Cronbach's alpha: } 0.683\end{array}$} \\
\hline $\begin{array}{l}\text { 25. It is important for me to treat a person as a whole when } \\
\text { treatment is performed. }\end{array}$ & 0.378 & 0.134 & -0.023 & $\mathbf{0 . 6 7 2}$ \\
\hline $\begin{array}{l}\text { 3. Spiritual, physical, and mental health should be dealt with as a } \\
\text { whole. The person who takes care of my health should also take } \\
\text { this into account. }\end{array}$ & 0.337 & 0.096 & -0.115 & $\mathbf{0 . 6 3 4}$ \\
\hline $\begin{array}{l}\text { 10. The health of our body and soul is maintained and sustained } \\
\text { by an energy or living force within us. }\end{array}$ & 0.440 & 0.247 & -0.010 & $\mathbf{0 . 6 0 6}$ \\
\hline $\begin{array}{l}\text { 12. Discomfort felt by the patient can be considered as a } \\
\text { disruption of the body's balance or impairments in organs that } \\
\text { affects the whole body. }\end{array}$ & 0.312 & 0.107 & -0.034 & $\mathbf{0 . 5 4 3}$ \\
\hline $\begin{array}{l}\text { 13. Health and disease are a reflection of the balance between } \\
\text { positive healing energy and negative destructive energy. }\end{array}$ & 0.400 & 0.287 & 0.020 & $\mathbf{0 . 5 1 5}$ \\
\hline $\begin{array}{l}\text { 15. A patient's expectations, health beliefs, and spiritual values } \\
\text { should be integrated in healthcare. }\end{array}$ & 0.417 & 0.241 & 0.072 & $\mathbf{0 . 5 0 7}$ \\
\hline $\begin{array}{l}\text { 23. Treatment approaches not based on scientific methods } \\
\text { should not be encouraged. }\end{array}$ & 0.179 & -0.207 & 0.109 & $\mathbf{0 . 3 9 3}$ \\
\hline $\begin{array}{l}\text { 2. The human body can heal itself and the duty of healthcare } \\
\text { providers is to facilitate this process. }\end{array}$ & 0.380 & 0.218 & 0.043 & $\mathbf{0 . 3 9 0}$ \\
\hline $\begin{array}{l}\text { 6. The positive effect of complementary medicine on health } \\
\text { stems from the belief that people are complementary medicine } \\
\text { (learned expectation). }\end{array}$ & 0.212 & 0.217 & -0.092 & $\mathbf{0 . 2 2 1}$ \\
\hline Proportion of total variance explained: 40.51\%; Cronbach's alpha: & 0.808 & & & \\
\hline *Varimax rotation applied. & & & & \\
\hline
\end{tabular}

\begin{tabular}{|c|c|c|c|c|c|c|c|c|c|}
\hline Items & 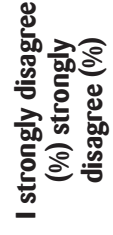 & 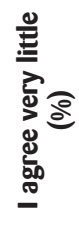 & 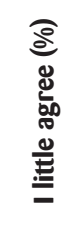 & 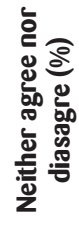 & 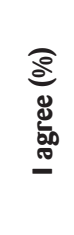 & 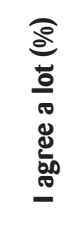 & 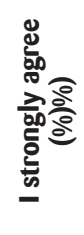 & 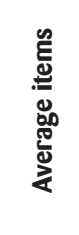 & 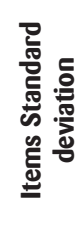 \\
\hline Item $1^{*}$ & 19.4 & 18.4 & 18.9 & 19,8 & 10,1 & 7,4 & 6,0 & 3,29 & 1,76 \\
\hline Item 2 & 6,2 & 7,7 & 11,6 & 16,1 & 16,9 & 16,4 & 25,1 & 4.80 & 1.86 \\
\hline Item 3 & 0.7 & 0.8 & 2.0 & 4.9 & 10.1 & 17.1 & 64.5 & 6.32 & 1.15 \\
\hline Item $4^{*}$ & 22.1 & 26.1 & 21.8 & 13.4 & 7.7 & 5.0 & 3.9 & 2.89 & 1.63 \\
\hline Item 5 & 11.2 & 15.9 & 15.7 & 23.3 & 14.4 & 11.1 & 8.4 & 3.80 & 1.76 \\
\hline Item 6 & 8.2 & 8.7 & 11.2 & 21.6 & 20.1 & 16.4 & 13.7 & 4.41 & 1.77 \\
\hline Item 7 & 8.4 & 7.2 & 10.4 & 19.4 & 16.6 & 18.8 & 19.3 & 4.62 & 1.85 \\
\hline Item 8T & 19.4 & 21.1 & 22.1 & 20.8 & 9.2 & 4.9 & 2.5 & 3.04 & 1.55 \\
\hline Item 9T & 3.2 & 4.7 & 6.5 & 13.2 & 12.4 & 19.1 & 40.9 & 5.48 & 1.71 \\
\hline Item 10 & 5.7 & 3.7 & 7.0 & 21.4 & 18.1 & 19.9 & 24.1 & 4.99 & 1.71 \\
\hline Item 11 & 35.3 & 13.6 & 10.7 & 13.7 & 12.1 & 7.7 & 6.9 & 3.04 & 1.99 \\
\hline Item 12 & 2.5 & 1.5 & 5.2 & 13.7 & 18.1 & 26.3 & 32.7 & 5.53 & 1.48 \\
\hline Item 13 & 6.4 & 4.7 & 7.0 & 27.5 & 21.8 & 18.1 & 14.6 & 4.66 & 1.63 \\
\hline Item 14 & 37.0 & 20.1 & 9.7 & 12.2 & 9.0 & 5.5 & 6.4 & 2.78 & 1.91 \\
\hline Item 15 & 4.5 & 4.5 & 7.7 & 15.9 & 16.6 & 18.4 & 32.3 & 5.20 & 1.74 \\
\hline Item 16 & 40.7 & 17.4 & 7.0 & 10.7 & 10.4 & 5.4 & 8.4 & 2.82 & 2.03 \\
\hline
\end{tabular}




\begin{tabular}{|c|c|c|c|c|c|c|c|c|c|}
\hline Items & 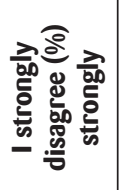 & 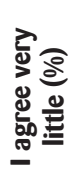 & 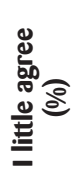 & 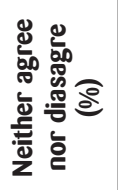 & 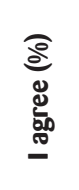 & 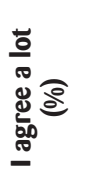 & 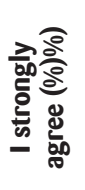 & 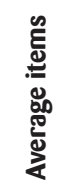 & 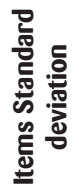 \\
\hline Item 17 & 17.8 & 13.9 & 10.9 & 17.3 & 15.4 & 12.7 & 12.1 & 3.85 & 1.99 \\
\hline Item 18 & 8.7 & 6.0 & 12.4 & 27.8 & 17.8 & 15.1 & 12.2 & 4.34 & 1.71 \\
\hline Item 19 & 10.9 & 8.7 & 12.2 & 27.8 & 15.7 & 13.4 & 11.2 & 4.14 & 1.77 \\
\hline Item 20 & 19.4 & 13.1 & 12.1 & 18.4 & 17.1 & 9.5 & 10.4 & 3.71 & 1.95 \\
\hline Item 21 & 5.5 & 5.4 & 12.4 & 21.4 & 20.8 & 19.3 & 15.2 & 4.65 & 1.66 \\
\hline Item 22 & 2.5 & 4.2 & 9.0 & 17.1 & 19.8 & 22.8 & 24.6 & 5.14 & 1.58 \\
\hline Item 23 & 15.1 & 5.4 & 6.0 & 15.6 & 11.1 & 15.1 & 31.8 & 4.75 & 2.16 \\
\hline Item 24 & 18.3 & 19.4 & 17.1 & 22.9 & 11.7 & 4.5 & 6.0 & 3.28 & 1.71 \\
\hline Item 25 & 2.5 & 2.0 & 4.2 & 7.0 & 9.5 & 19.9 & 54.8 & 5.98 & 1.50 \\
\hline Item $26^{*}$ & 24.1 & 24.6 & 22.3 & 14.4 & 4.5 & 5.0 & 5.0 & 2.86 & 1.67 \\
\hline Item 27 & 26.1 & 14.4 & 8.9 & 13.6 & 10.7 & 11.2 & 15 & 3.62 & 2.19 \\
\hline
\end{tabular}

Recognition objects of CACMAS is assessed by $27 \%$ parts by comparing the subdivisions and upper sections followed by assessment of extent validation.10 A significant difference was found between the subdivision and upper sections $(p<0.001)$, showing that high and low scores are able to discriminate the objective properties presented in the scale.

\section{Reliability}

The reliability of the CACMAS was evaluated according to its internal consistency, and by using the test-retest method and substance-counting point correlation. ${ }^{11}$ The Cronbach's alpha coefficients of the CACMAS subscales are presented in Table 3. In an item analysis, correlation between the scale and counting totally number $4,6,8,9,23$, and 26 was $<0.30$, and when the Cronbach's alpha value of the scale was excluded, this value did not change significantly (range: 0.792-0.815). Therefore, these items were not excluded from the adapted CACMAS. The Cronbach's alpha value of the adapted CACMAS was 0.808 , and those of its subscales ranged between 0.683 and 0.825 (Table 3).

Table 3. Substance and Cronbach Alpha Coefficient Distributions of Complementary, Alternative and Conventional Medicine Attitude Scale Subscale Factor Dimensions

\begin{tabular}{|l|c|c|c|c|c|c|c|}
\hline Factor dimensions & $\begin{array}{c}\text { Number of } \\
\text { Items }\end{array}$ & $\begin{array}{c}\text { Cronbach } \\
\text { Alfa }\end{array}$ & Median & 25th perc. & 75th perc. & Max & Min \\
\hline $\begin{array}{l}\text { Philosophical } \\
\text { congruence with } \\
\text { complementary and } \\
\text { alternative medicine }\end{array}$ & 8 & 0,825 & 36,00 & 30,00 & 42,00 & 56,00 & 10,00 \\
\hline $\begin{array}{l}\text { Dissatisfaction } \\
\text { with conventional } \\
\text { medicine }\end{array}$ & 10 & 0,796 & 32,00 & 23,00 & 40,00 & 67,00 & 10,00 \\
\hline Holistic balance & 9 & 0,683 & 47,00 & 41,00 & 53,00 & 63,00 & 16,00 \\
\hline
\end{tabular}

To determine the stability of CACMAS scores over time, the scale was completed by 55 participants over a 4-week period. There was no significant change in the total number of points during 
this period $(p=0.118)$. A strong correlation between the answers to items on first and second dimension factors ( $r=0.744, p<0.001$ and $r=0.696, p<0.001$, respectively) and a medium level of positive correlation ( $r=0.369, p=0.006$ ) were seen over the 4-week period. Complementary factor analysis of compliance $(2=1,644.07$, degrees of freedom $(d f)=324 ; p<0.001)$ produced the following values: RMSEA, 0.090; GFI, 0.809; and AGFI, 0.777 .

Of the participants, $43 \%$ (257) stated that they used at least one type of CCMP. The most common reason for using CCMP was pain relief (40\%), especially for the muscles and joints (15.4\%), back and waist (13.5\%), and head (7\%). The second most frequent reason for CCMP use was upper respiratory system infection (12\%).

Of the participants who used CCMP, 24.3\% reported that they were cured completely, $64.7 \%$ that they were cured partially, $8.9 \%$ that they were undecided, and $2.1 \%$ that they were not cured. The majority of participants accessed information on CCMP via the internet (65.3\%), television (51.4\%), and books (38.2\%), while 20\% stated that they had learned about CCMP from their grandparents. Approximately one-third (33.7\%) of the participants chose to use CCMP due to ease of access; approximately one-quarter described CCMP as "complementary" (25.8\%) and another one-quarter as "reliable" (24.8\%). The majority of participants has used CCMP previously and indicated the belief that there are significant differences between individuals who use CCMP and those who do not $(p<0.001)$.

The total number of points on the CACMAS was higher for women than men $(p=0.021)$, including the points totals of all three subscales. While the points difference was not significant for the subscale of "dissatisfaction with conventional medicine" ( $p=0.063)$, there were significant points differences between the genders for the "philosophical congruence with complementary and alternative medicine" and "holistic balance" subscales ( $p=0.364$, and $p=0.006$, respectively) (Table 4).

\begin{tabular}{|c|c|c|c|c|c|c|c|}
\hline & Gender & Median & 25. perc. & 75. perc. & $\min$ & $\max$ & $\mathbf{p}^{*}$ \\
\hline \multirow{2}{*}{$\begin{array}{l}\text { Philosophical } \\
\text { congruence with } \\
\text { complementary and } \\
\text { alternative medicine }\end{array}$} & Male & 36,0 & 30,00 & 41,00 & 10,00 & 56,00 & \multirow[t]{2}{*}{0,063} \\
\hline & Female & 37,0 & 30,75 & 43,00 & 14,00 & 56,00 & \\
\hline \multirow{2}{*}{$\begin{array}{l}\text { Dissatisfaction } \\
\text { with conventional } \\
\text { medicine }\end{array}$} & Male & 31,0 & 23,00 & 40,00 & 10,00 & 67,00 & \multirow[t]{2}{*}{0,364} \\
\hline & Female & 32,5 & 24,00 & 40,00 & 10,00 & 64,00 & \\
\hline \multirow{2}{*}{ Holistic balance } & Male & 47,0 & 41,00 & 52,00 & 16,00 & 63,00 & \multirow[t]{2}{*}{0,006} \\
\hline & Female & 49,0 & 42,00 & 53,25 & 18,00 & 63,00 & \\
\hline
\end{tabular}

A total of 249 participants $(41.7 \%)$ reported that they had some knowledge of traditional and complementary medicine, while $130(21.8 \%)$ reported that they knew nothing about the topic and 218 (36.5\%) were uncertain.

No statistically significant difference was found in attitudes toward traditional and complementary medicine according to age $(p=0.127)$.
Sakarya Med]

2018;8(4):726-736

KöSE et al. CACMAS: Turkish Validity Reliability Study 


\section{Discussion}

There is no Turkish language scale that indexes the attitudes of individuals toward traditional and complementary medicine. However, two scales have been modified and translated into Turkish from other languages to address this: the first of these scales, the Integrative Medicine Attitude Questionnaire (IMAQ), consists of 29 questions and was developed by Schneider, Meek, and Bell (2003) to determine the attitudes of health occupies. Two subscales explain $38 \%$ of the variance in IMAQ scores The Cronbach's alpha of the scale was reported as 0.89 and those of its two subscales were 0.91 and $0.72 .{ }^{12}$ Moreover, the Cronbach's alpha of the IMAQ adapted for use in Turkish populations was 0.64 according to Engin et al. ${ }^{13}$ The second scale, the Holistic Complementary and Alternative Medicine Questionnaire (HCAMQ), was developed by Hyland, Lewith, and Westoby and contains 11 questions divided between two subscales. ${ }^{14}$ The HCAMQ was designed to determine the attitudes of the general population to alternative medicine. ${ }^{12,15-19}$ This scale was completed by 50 newly enrolled polyclinic patients and 50 rheumatology polyclinic patients. The Cronbach's alpha of the scale was reported as 0.80 , and those of its two subscales were 0.83 and $0.75 .{ }^{14}$ The HCAMQ was further investigated in a study including 448 primary care center patients, which reported that the Cronbach's alpha of the scale was 0.72 , and those of its two subscales were 0.62 and 0.60 . The adapted CACMAS used in this study is more in-depth than the HCAMQ, as it contains 27 questions divided among three subscales..$^{13,20,21}$

CCMP is used to improve self-strength and for protection against disease; thus, this study was done to facilitate individuals' pursuit of health.

To conduct a factor analysis, the study sample should be large enough to ensure safety correlation. In this study, before determining the factorial structure of the CACMAS, the KMO test of sampling adequacy and Bartlett's test of sphericity were performed to verify that there was a sufficiently large sample size. A KMO value close to 1 indicates an adequate sample size, and the KMO value obtained in this study was 0.852 .8 Bartlett's test of sphericity indicated that there are significant high levels between variables and that the data were suitable for exploratory factor analysis ( 2 = $4,910.768, p<0.001)$.

Factor analysis is used to identify related variables, enabling researchers to group such variables and produce subscales for further analysis. ${ }^{22}$ Exploratory factor analysis, as applied in this study, is specifically used to identify closely associated variables.

McFadden et al. produced the original 27-item CACMAS, which can be divided into three subscales using basic element analysis. In our analysis, the eigenvalues of all items were $>1$. Factor analysis was done to derive three subscales, which together explained $40.51 \%$ of the total variance. As variance increases, the factorial structure becomes stronger.

The internal consistency of the CACMAS was evaluated using Cronbach's alpha, which is expressed as a number between 0 and 1 . Internal consistency refers to the extent to which all test items measure the same concept or construct. Hence, it varies according to the degree of inter-relatedness among all items on a test; when the items are highly correlated, the Cronbach's alpha value is high. ${ }^{23}$ 
A Cronbach's alpha value of $0.80-1.00$ indicates a highly reliable test; a value of $0.60-0.79$ is considered reliable, a value of $0.40-0.59$ indicates low reliability, and a value of $0.00-0.39$ indicates an unreliable test. ${ }^{8}$ The Cronbach's alpha value of our adapted scale was 0.808 , and the values for the 8-item "philosophical congruence with complementary and alternative medicine" subscale, 10-item "dissatisfaction with conventional medicine" subscale, and 9-item "holistic balance" subscale were $0.825,0.796$, and 0.683 , respectively. Thus, our adapted CACMAS is very reliable, similar to the original scale, which has a Cronbach's alpha value $>0.60$ (13-item "philosophical congruence with complementary and alternative medicine" subscale, 6-item "dissatisfaction with conventional medicine" subscale, and 4-item "holistic balance" subscale alpha Cronbach's values of $0.88,0.78$, and 0.79 , respectively).

Internal consistency was assessed by testing the single-item reliability of the adapted CACMAS. The variance of each item and total variance of the scale were calculated and any associations were noted. ${ }^{17}$ The Cronbach's alpha values for scale items ranged from 0.825 to 0.683 , with no significant differences in the values among the items. Therefore, all original CACMAS items were included in the adapted scale. The IMAQ of Schneider, Meek, and Bell (2003) comprises two subscales that explain 38\% of the variance in total IMAQ scores and have Cronbach's alpha values of 0.91 and 0.72. Ergin et al. determined the Cronbach's alpha value of the IMAQ scale to be $0.64 .12,13$ Moreover, the Cronbach's alpha of the HCAMQ, which was previously used in a Turkish population, was 0.72 , and that of its subscales ranged between 0.60 and $0.62 .{ }^{18}$ These findings indicate that the total and subscale Cronbach's alpha values of our adapted CACMAS were higher than those of the IMAQ and HCAMQ.

Similar to the literature, we found that women and individuals with chronic diseases were more likely to seek out CCMP. ${ }^{24-28}$ The participants in this study were young, since our sample included only individuals who worked and the age limit for inclusion was 65 years. This represents a limitation, as our sample does not reflect the aging population of Turkey. Moreover, the education level of the participants was high ( $82.4 \%$ attended high school or had some higher education); thus, the results of this study cannot be generalized to individuals with lower education levels.

\section{Conclusion}

The CACMAS is a valid and reliable scale that can be used to determine societal trends in, and changes in attitudes toward, traditional and complementary medicine. The original CACMAS contains no cut-off value but includes three subscales. In this study, the validity and reliability of our adapted CACMAS was examined and the Cronbach's alpha value was 0.808 , indicating that is a very reliable scale. None of the 27 items in the original scale were excluded from our adapted scale. Similar to the original scale, the following three subscales comprised the adapted CACMAS: "philosophical congruence with complementary and alternative medicine", 8 items; "dissatisfaction with conventional medicine", 10 items; and "holistic balance", 9 items.

Of the study participants, 249 (41.7\%) reported having knowledge of traditional and complementary medicine, while $130(21.8 \%)$ reported that they knew nothing about the topic and 218 (36.5\%) were uncertain. People who advice CACMAS other people take higher points then who do not $(p<0.001)$. The likelihood of using CCMP is affected by an individual's perspective on healthcare, the treatment options available for a given disease, and communication within the
Sakarya Med J

2018;8(4):726-736

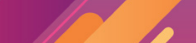


healthcare system. Moreover, societal acceptance of health services by society delivered by primary, secondary, and tertiary care centers is important. The CACMAS can be used to determine the attitudes of society toward traditional and complementary medicine, to facilitate the planning of health services; thus, it might be helpful in tailoring health policies according to the values and needs of society. The validity and reliability of our adapted CACMAS should be examined in regions in Turkey differing in sociocultural and socioeconomic terms. 
1. McFadden KL, Hernandez TD, Ito TA. Attitudes toward complementary and alternative medicine influence its use, EXPLORE November/December 2010, Vol. 6, No. 6, p 380-388

2. Baer $\mathrm{H}$. The emergence of integrative medicine in Australia The growing interest of biomedicine and nursing in Comcomplementary medicine in a southern developed society. Med Anthropol Q 2008;22:52-66.

3. Khalaf AJ, Whitford DL. Theuse of Complementary and alternative medicine by patients with diabetes mellitus in Bahrain: A cross-sectionalstudy. BMC ComplementAlternMed 2010;10:35.

4. Eisenberg DM, Kessler RC, Foster C, Norlock FE, Calkins DR, Delbanco TL. Unconventionalmedicine in the United States. Prevalence, costs, andpatterns of use. N Engl J Med 1993;328:246-52.

5. Fisher $\mathrm{P}$ and Ward A. Complementary medicine in Europe. BMJ 1994 Jul;309(6947):107-111.

6. Betthauser LM, Brenner LA, Forster JE, Hostetter TA, Schneider AL, Hernandez TD. A Factor Analysis and Exploration of Attitudes and Beliefs Toward Complementary and Conventional Medicine in Veterans, Medical Care, Volume 52, Number 12 Suppl 5, December 2014, p 50-56.

7. Davis, L.L. Instrument review: Getting the most from a pa nel of experts. Applied Nursing Research, 1992, 5, 194 197.

8. Alpar R, Uygulamalı Çok Değişkenli i̇statistiksel Yöntemler, 4.Baskı, Ankara, s 269-302, 849.

9. Erkorkmaz Ü, Etikan i, Demir O, Özdamar K, Sanisoğlu SY Doğrulayıcı Faktör Analizi ve Uyum İndeksleri, Türkiye Klinikleri J MedSci 2013;33(1), s 210-223.

10. Tezbaşaran A. Likert Tipi Ölçek Geliştirme Kılavuzu. İkinci baskı, Ankara, Türk Psikologlar Derneği, 1997.

11. Bhattacherjee A. Social Science Research: Principles, Methods, and Practices, p:56-58, 2012, ISBN-13: 978 1475146127

12. Schneider CD, Meek PM, Bell IR. Development and validation of IMAQ: Integrative Medicine Attitude Questionnaire, BMC MedicalEducation 2003, 3:5

13. Ergin A, Hatipoğlu C, Bozkurt Ai, Mirza E, Kunak D, Karan C, Özçelik G, Teğin C, Pazır Y, Pırtı İ. Knowledge andattitudes of residentsandmedicalstudents on complementary-alternativemedicine, Pam Tıp Derg 2011;4(3):136-143.

14. Hyland ME, Lewith GT, Westoby C. Developing a measure of attitudes: the holistic complementary and alternative medicine questionnaire. Complement Ther Med. 2003 Mar; 11(1):33-8

15. Desylvia D, Stuber M, Fung CC, Bazargan-Hejazi S, Cooper E. The knowledge, attitudes and usage of complementary and alternative medicine of medical students. Evid Based Complement Alternat Med. 2011:ID, 728902. Sayfa, doi: 10.1093/ecam/nen 075 .
16. Tanrıöğen A. Bilimsel Araştırma Yöntemleri, 3. Baskı. Ankara, Anı Yayıncılık, 2012: 172. Kültürlerarası ölçek uyarlaması için rehber I: Ölçek uyarlama aşamaları ve dil uyarlaması, Aksayan S, Gözüm S, Hemşirelik Araştırma Dergisi 2002 4(1).

17. Aksayan S, Gözüm S. Kültürlerarası Ölçek Uyarlaması İçin Rehber I: Psikometrik Özellikler ve Kültürlerarası Karșlaștırma. Hemşirelik Araştırma Geliştirme Dergisi 2002;4(2):913

18. Kalaycı, Ş. (2010), Faktör Analizi, Ed. Şeref Kalaycı, SPSS Uygulamalı Çok Değişkenli İstatistik Teknikleri, Asil Yayın Dağııım Ltd. Şti. Ankara.

19. Erci B, Attitudes towards holistic complementary and alternative medicine: a sample of healthy people in Turkey, Complementary and alternative medicines, Journal of Clinical Nursing, 16, 761-768,2007, doi:10.1111/j.1365 2702. 2006. 01655.x.

20.Lie DA, Boker J.Comparative survey of complementary and alternative Medicine (CAM) attitudes, use, and in formation-seeking behaviour among medical students, residents\&faculty, BMC Med Educ. 2006 Dec 9;6:58.

21. Chaterji R, Tractenberg RE, Amri H, Lumpkin M, Amorosi $\mathrm{SB}$, Haramati A large-samplesurvey of first- andsecondyearmedicalstudentlarge-samplesurvey of first- andsecond-yearmedicalstudentattitudestowardcomplementaryandalternativemedicine in thecurriculumand in practice. AlternTherHealthMed. 2007 Jan-Feb;13(1):30-5.

22. Kalaycı, Ş. (2010), Faktör Analizi, Ed. Seref Kalaycı, SPSS Uygulamalı Çok Değişkenli istatistik Teknikleri, Asil Yayın Dağııım Ltd. Şti. Ankara.

23. Tavakol M, Dennick R, Making sense of Cronbach's alpha, International Journal of Medical Education. 2011; 2:53-55

24. Pettersen S, OlsenRV. Exploring Predictors of Health Sciences Students' Attitudes Towards Complementary-Alternative Medicine, Adv Health Sci Educ Theory Pract (2007) 12 35. doi:10.1007/s10459-005-3054-1.

25. Ventola L, Current Issues Regarding Complementary and Alternative Medicine (CAM) in the United States Part 1: The Widespread Use of CAM and the Need for Better-Informed Health Care Professionals to Provide Patient Counseling, Vol.2010;35(8): 461-68

26. Xue CC, Zhang AL, Lin V, Da Costa C, Story DE. Complementary and alternative medicine use in Australia: A national populationbased survey. J Altern Complement Med 2007;13:643-50.

27. Harmon S, Ward CB. Complementary And Alternative Me dicıne: Awareness And Attitudes. AHCMJ, 2007;3:1.

28. Saydah SH, Eberhardt MS. Use of complementary and alternative medicines among adults with chronic disease: United States 2002. J Altern Complement Med 2006;12: 805-12.
Sakarya Med $]$ 2018;8(4):726-736

KÖsE et al. CACMAS: Turkish Validity Reliability Study 